\title{
BIOLOGICAL POLLUTION OF THE FLORA OF VOLYN' POLISSYA IN UKRAINE BY ALIEN PLANTS
}

\author{
Vitaliy VolOdYMYRETS $^{1 *}$, Larisa OYTSIUS ${ }^{2}$, Serhiy HUTSMAN ${ }^{1}$, Lyubov SAVCHUK ${ }^{2}$
}

${ }^{1}$ National University of Water and Environmental Engineering, Soborna Str. 11, 33028 Rivne, Ukraine

${ }^{2}$ Rivne State Humanitarian University, S. Bandery Str. 12, 33000 Rivne, Ukraine

*Corresponding author. E-mail: volodymyretsvo@ukr.net

\begin{abstract}
Volodymyrets V., Oytsius L., Hutsman S., Savchuk L., 2021: Biological pollution of the flora of Volyn' Polissya in Ukraine by alien plants. - Botanica, 27(1): 69-76.

This study aimed to analyse biological pollution of the native flora of Volyn' Polissya in Ukraine by alien plant species. According to the research results, 364 alien plants belonging to 228 genera and 68 families were identified in the spontaneous flora of Volyn' Polissya. The spectrum of the most species-rich families of the alien fraction of the region's flora includes Asteraceae, Brassicaceae, Poaceae, Rosaceae, Chenopodiaceae, Fabaceae, Lamiaceae, Solanaceae, Caryophyllaceae. As a result of the phytopollution, at least 16 families were included in the region's flora. Four species currently in a stage of expansion were identified (Reynoutria japonica, Impatiens parviflora, Echinocystis lobata, Bidens frondosa). By origin, the species of the alien fraction of the region's flora are dominated by the immigrants from the Mediterranean, Iranian-Turan and Atlantic-North American floristic regions. Over the past 30-50 years, at least 80 new species of alien plants have been introduced into the territory of Volyn' Polissya. Over the past 5-7 years, the speed of the spread and naturalisation rate of species such as Quercus rubra, Asclepias syriaca, Parthenocissus quinquefolia, Prunus cerasifera, Hippophae rhamnoides, Oenothera biennis has increased. These species intensively invade the native plant communities. Phytopollution of Volyn' Polissya is promoted by the migration of alien species from agricultural lands and escaping from cultivation. This process is also facilitated by urbanisation and the development of transport infrastructure.
\end{abstract}

Keywords: alien flora, naturalisation, phytopollution, plant invasion, transforming species, Volyn' Polissya.

\section{INTRODUCTION}

The spread of alien, also known as non-native, plant species has acquired a global character and has covered all continents (РRоTороpova et al., 2002). This process determines the biological pollution of the territories and is one of the main factors for transforming the native floras of different regions (РROTOPOPOVA et al., 2003). Naturalisation of alien species is changing the typical region ratio of taxa. Under the influence of phytopollution, the floristic proportions change, species of native plants are displaced from the composition of regional floras. As a result, such floras gradually lose their specific features, their unification occurs (РRоторороva et al., 2002). This poses a direct threat to the conservation of natural biodiversity (PROTOPOPOVA et al., 2003). Naturalisation processes initiate the development of plant invasion and should be considered one of the main directions of modern florogenesis (РRоTOPOPOVA et al., 2002; VOLODYMYRETS' et al., 2013).

In the Global Strategy on Invasive Alien Species (McNeely et al., 2001), which was developed by an international group of leading experts in 2001, the spread of invasive species is recognised as the main threat to biodiversity, habitats and ecosystems, and subsequently - production of ecologically safe food 
and human health. Nowadays, an essential measure of European environmental policy is assessing threats from the introduction and spread of alien species, especially invasive ones. The task is to compile a priority list of species whose naturalisation can have significant environmental and economic consequences (Roy et al., 2015; Branquart et al., 2016; CARBonERAS et al., 2017; EuROPEAn COMMISSION, 2017). For Ukraine, which occupies a relatively large territory of the European continent, it is essential to consider European policies concerning invasive alien species (IvAshCHENKo \& Burda, 2014; Burda et al., 2015).

The problem of introduction of alien species is devoted to a large number of publications, in which various aspects of the study of this phenomenon are presented: from the general theoretical questions of the process of naturalisation of alien species and the methodological approaches of their research and analysis until clarifying the bioecological features and the distribution of specific alien plant, their role in the flora of different regions (РRоторороva et al., 2003; Burda, 2006; Hutsman et al., 2009; LuKash, 2009; Mosyakin, 2009).

The processes of introduction and naturalisation of alien species create a real threat to the plant diversity in the territory of Ukraine. Currently, its spontaneous flora has at least 830 species of alien vascular species (which comprise at least $14 \%$ of the total number of flora species in the country), among which 85 species are characterised by high invasiveness, and another 31 species are potentially invasive (Protopopova et al., 2003). Observations testify to the progress of this process: increase the tempo of the escaping, the spread and degree of naturalisation of alien species are growing. Now in the flora of Ukraine, there is no floristic complex in which there would be no alien plant species (PROTOPOPOVA et al., 2002; Protopopova et al., 2003).

A general analysis of the synanthropic flora of Ukraine and its alien fraction in the early 1990's was held by V. Protopopova (Protopopova, 1991). The features of naturalisation of individual groups of alien plants in Ukraine have been studied by РRоTOPopova \& SHeVERa (2014) and Burda (2017).

Due to the peculiarities of natural and socio-economic conditions, until recently, Ukrainian Polissya and Volyn' Polissya, have been considered the least exposed to biological pollution (OYTSYUS', 2011).
However, over the past 30 years, conditions created here assisted in the immigration and naturalisation of alien plant species to the Polissya flora. Such phenomena as the growth of the area of cities and the increase of the urban population, the conduct of large-scale drainage, the development of sizes of industrial and agrarian production, an increase in the range of cultivated flower-decorative species and plant forms, and the activation of transport links facilitated this process (Volodymyrets' et al., 2013). At the same time, there was a deterioration in the increasing number of scrapyards in towns and villages, sanitary condition of cities and towns located in the region, an increase in an abandoned field and unused land area (Hutsman et al., 2009; Oytsyus', 2011; Volodymyrets' et al., 2013). Climate changes also contribute to the naturalisation of alien species (Oytsyus', 2011). These phenomena are accompanied by climate change, first, the softening of the winter period and the increase of continental climate (IvanYuta et al., 2020).

The study results on alien plant species in the territory of Volyn' Polissya have been published in several previous works (HuTSMAn et al., 2009; OYTSYus', 2011; Volodymyrets' et al., 2013). The purpose of our research was to clarify the peculiarities of the biological pollution of the flora of Volyn' Polissya of Ukraine by species of plants by analysing the distribution and naturalisation of such species in the region.

Volyn' Polissya is one of the physical and geographical regions of Ukraine and occupies the extreme northwest part of its territory. In the north, it borders with the Republic of Belarus, and in the west - with Poland. From the south, it is adjacent to the Volyn' Upland, and in the east, it passes into Zhytomyr Polissya. The study region covers the northern part of the Volyn' and Rivne administrative regions $\left(28.1 \mathrm{~km}^{2}\right)$ (NATSIONAL'NYy Atlas ..., 2008).

By its age, the modern natural flora of the region is a young allochtonous complex of species, which has formed in the post-glacial period - in the Holocene. According to the floristic zoning, Volyn' Polissya includes five floristic districts belonging to two counties of the Polissya sub-province of the Eastern European province of the European region of the Holarctic kingdom (SHELYAG-SosOnKO, 1985).

The research aimed to assess the biological con- 
tamination by alien plants in Volyn' Polissya of Ukraine. The authors set the task to determine the species composition of alien plants and their impact on the aboriginal flora of the region.

\section{MATERIALS AND METHODS}

The basis for the analysis was materials received during field research in different parts of Volyn' Polissya in 2003-2019. The material from the Herbariums of the National University of Water and Environmental Engineering (RIVUN, Rivne) and Lesya Ukrainka Eastern European National University (Lutsk) were also used. Groups of species by the time of introduction were given according to J. Kornás (KoRNÁs, 1968), eukenophytes (alien species that have been introduced since the beginning of the twentieth century) were singled out. The degree of naturalization of alien plants was analyzed based on the concept odf phases of overcoming barriers that an alien species has overcome and successfully established (RICHARDSON et al., 2000). The names of the species are given using the base of the information resource for the Euro-Mediterranean Plant Diversity (Euro +Med, 2011).

\section{RESULTS AND DISCUSSION}

According to the results of the research, 364 species of alien plants belonging to 228 genera and 68 families were detected (approximately 23\% of the total number of species of spontaneous flora in the region and about $40 \%$ of the total number of alien species recorded throughout Ukraine) (РRоторовоva et al., 2002). Naturalised species comprise $72.3 \%$ of the total number of alien species, whereas casual species comprise $27.7 \%$.

Considering the number of naturalised alien species of Volyn' Polissya, the average level of phytopollution in the region is almost $16 \%$ (fraction of the total number of species in the region), and this indicator coincides with the Forest-steppe of Ukraine (Burda et al., 2015).

The spectrum of the most significant number of families' fractions that were represented by ten or more species includes nine families: Asteraceae (57 species), Brassicaceae (33 species), Poaceae (28 species), Rosaceae (27 species), Chenopodiaceae and Fabaceae (17 species), Lamiaceae (12 species), Solanaceae (11 species), Caryophyllaceae (10 species) (Fig. 1). All the above-mentioned families include 212 species $(58.2 \%$ of the total alien species number). The comparison of the spectrum mentioned above with that of the native flora of Volyn' Polissya shows the influence of the ancient Mediterranean region since such families as Brassicaceae, Fabaceae, Lamiaceae, Caryophyllaceae are considered to be characteristic families (TAKHTAJAN, 1986). Also, the family Chenopodiaceae is considered a typical representative of the desert flora (TAKHTAJAN, 1986). At the same time, the prominent presence in the given spectrum of Rosaceae and especially Solanaceae, reflects the influence of immigrants from North and South America (OyTsyus', 2011). The alien fraction of the region's flora contains many families and genera represented by one or 2-3 species (the proportion of such families and genera is about $50 \%$ and more than $80 \%$ of the total number of these taxa fractions). It should be noted that as a result of the introduction of alien species, the region's flora includes at least 16 families: Amaranthaceae, Nyctaginaceae, Moraceae, Phytolaccaceae, Portulacaceae, Juglandaceae, Cucurbitaceae, Resedaceae, Commelinaceae, Xanthorrhoeaceae, Rutaceae, Anacardiaceae, Elaeagnaceae, Vitaceae, Hydrangeaceae, Verbenaceae, and over 100 genera such as Reynoutria, Thladiantha, Bryonia, Echinocystis, Diplotaxis, Raphanus, Sisymbrium, Reseda, Morus, Cannabis, Amelanchier, Oenothera, Lupinus, Robinia, Aesculus, Rhus, Parthenocissus, Aethusa, Conium, Asclepias, Datura, Elsholtzia, Grindelia, Iva, Ambrosia, Galinsoga, Tripleurospermum, Cichorium, Elodea, Secale, Hordeum, Anisantha, Zizania, Eragrostis,

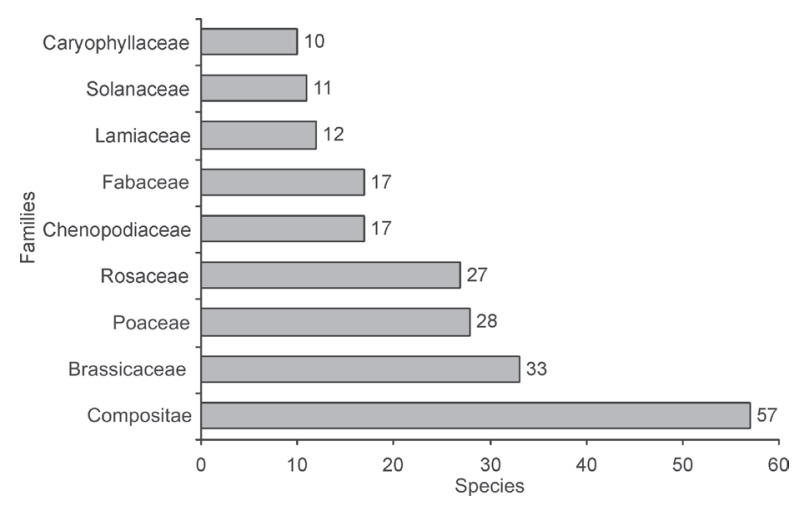

Fig. 1. The spectrum of the most numerical families of the alien fraction of the flora of Volyn' Polissya of Ukraine 
Panicum, Echinochloa, Setaria, Acorus, etc., which are not represented in its native fraction. These facts indicate noticeable biological pollution of the region's territory and the transformation of its natural flora (Hutsman et al., 2009; Oytsyus', 2011).

A feature of the biomorphological structure of the alien fraction in Raunkiaer's system is the high proportion of therophytes (RAUNKIAER, 1934), which comprised $51.4 \%$. The domination of therophytes is characteristic of the desert and semi-desert regions of the Mediterranean (WhitTAKER, 1975; TAKHTAJAN, 1986). Thus, such a noticeable presence of therophytes, on the one hand, indicates an increase in xeromesophytic conditions in the territory of Volyn' Polissya on the background of a massive spread of sandy and sandy loam soils, and, on the other hand, it reflects the Mediterranean origin of many species of alien plants. Many species of cultivated plants and then escaped are also represented by phanerophytes (about $17.0 \%$ ), the leading representatives of which are woody plants.

An analysis of the distribution of species in the territory of the studied region indicates that only one-third of the alien species is presented relatively equally, more than $32 \%$ rarely occur, almost $35 \%$ of the species have a limited distribution, up to 25 localities are known for them. Some species are found only in 1-10 localities, beyond which their spread is slowly. The distribution of certain species has a local character as they grow on a restricted area, and outside this area, these species are not spreading. However, in this area, they are successfully naturalised, often have high coverage and are active competitors with native species. Distributed species are represented by: Heracleum sosnowskyi Manden., Spiraea japonica (L.) Desv., Populus laurifolia Ledeb., Rosa rugosa Thunb., Tulipa sylvestris L., Zizania latifolia (Griseb.) Stapf, Lepidium campestre (L.) W.T. Aiton and Asclepias syriaca L. In the southern part of Volyn' Polissya, the most common species are Hordeum vulgare subsp. distichon (L.) Körn., $\times$ Sorbaronia mitschurinii (A.K. Skvortsov et Maitul.) Sennikov, Cannabis sativa L., Althaea officinalis L., Diplotaxis tenuifolia (L.) DC., Fagopyrum tataricum (L.) Gaertn., Blitum bonus-henricus (L.) Rchb., Lipandra polysperma (L.) S. Fuentes et al., Lycium barbarum L., Nepeta cataria L., Carduus nutans L., Matricaria discoidea DC., Rudbeckia laciniata L., Lonicera tatarica L., Aethusa cynapium L.
By origin, immigrants from Mediterranean, Iranian-Turan and Atlantic-North American flora regions dominate among the alien species of the region's flora, comprising $69.4 \%$ of species. Thus, the main geographical regions of the plant introduction into Volyn' Polissya area were from the north-eastern part of North America, the Ancient Mediterranean and the southern Eurasian. The naturalisation of new North American plants in the native communities of the region is most likely; it is explained by some similarity of the natural conditions of Polissya with the conditions of their native range. As for the Mediterranean and South Asian species, their naturalisation contributes to the changes of climatic conditions in the study area in the direction of increase in temperature and decrease in soil moisture (РвотоPOPOVA, 1991), primarily the softening of the winter period and the reduction of precipitation in summer, significant distribution of sandy and sandy loam soils (Oytsyus', 2011; Ivanyuta et al., 2020).

Analysis of alien species by the time of introduction showed that eukenophytes significantly predominate among them, the share of which in the alien fraction is $37.6 \%$ (137 species), the percentage of kenophytes is high $(31.6 \%$ or 115 species $)$, archeophytes are slightly less represented $(30.8 \%$ or 112 species). This ratio indicates a positive trend of the introduction of new alien species. The total share of kenophytes and eukenophytes reached almost 70\%; according to this indicator, it is equal to or exceeds the individual urban floras of Ukraine. Many Ukrainian urban floras have such or significantly exceeding indicator, which shows that the rate of introduction and naturalisation of alien plants has been growing over the past 70 years.

The dynamics of the species composition of the alien flora shows that for the last 30-50 years, at least 80 species have appeared in Volyn' Polissya as new species. For example, Equisetum ramosissimum Desf., Tulipa sylvestris, Setaria verticillata (L.) R. Beauv., S. italica subsp. pycnocoma (Steud.) De Wet, Prunus pumila L., Sanguisorba minor subsp. balearica (Nyman) Muñoz Garm. et C. Navarro, Thladiantha dubia Bunge, Hesperis pycnotricha Borbas et Degen, Amaranthus powelli S. Watson, Sisymbrum volgense E. Fourn., Phytolacca acinosa Roxb., Oxybaphus nyctagineus (Michx.) Sweet, Impatiens glandulifera Royle., Symphytum asperum Lepech., 
Nicandra physalodes (L.) Gaertn., Bidens frondosus L., B. connatus Willd., Centaurea diffusa Lam., Helianthus laetiflorus Pers., Grindelia squarrosa (Pursh) Dunal, Rudbeckia laciniata, Carduus nutans, Ceratochloa cathartica (Vahl) Herter, Glyceria striata (Lam.) Hitchc. and others. Previously, these species were not known in the region. At the same time, for these species, based on our research observations, such as Matricaria discoidea, Xanthium strumarium L., Solanum nigrum L., Trifolium hybridum L., Lepidium ruderale L., Silene gallica L., Thlaspi arvense L., Lamium album L., in the last 10-15 years there is a decrease in the number of localities and the number of populations, and non-native plants such as Hyoscyamus niger L., Datura stramonium L., Althaea officinalis, Agrostemma githago L. have become quite rare (OYTSYUs', 2011).

The degree of naturalisation of alien plants was analysed based on the concept of phases of overcoming the main barriers of the process can be defined based on the relevant barrier(s) that are overcome (RichARDSON et al., 2000). It was found that only 22 species $(6.0 \%)$ overcame the geographical barrier. Currently, the future of these species is uncertain, because it is unknown whether they are fully naturalised in the new territory. This group includes certain cultivated species near agricultural lands in the wild (for example, Zea mays L., Cucurbita pepo L., Lycopersicon esculentum Mill.). Only 79 species (21.7\%) overcame environmental barriers (21.7\%). The reproductive barriers were crossed by four species $(1.1 \%)$. They reproduce vegetatively or by seed, but almost do not spread beyond the site of their initial introduction. The other 64 species $(17.6 \%)$ overcame the local spread barrier, and their distribution is local, while 121 species $(33.2 \%)$ overcame the environmental barrier in human-modified or alien-dominated vegetation. These species are widespread in the region and grow in transformed ecotopes as part of plant communities heavily modified by humans. Species of this group prefer areas where vegetation has been destroyed and where the ground cover has been disturbed. Seventy-four species $(20.4 \%)$ overcame environmental barriers in natural or seminatural vegetation and took stable positions in natural or similar phytocenoses. These species are invasive plants (Fig. 2). Given this species distribution to overcome the main barriers, in the flora of Volyn' Polissya, 259 species $(71.2 \%$ of the total alien fraction) are naturalised plants.

Using a unified classification of alien species (BLACKBURN et al., 2014), an approximate assessment of their impact on natural ecosystems for invasive plants was conducted. Respectively nine and 15 species belong to the most significant class and have considerable influence. The total share of these species is $6.6 \%$ of the alien species, including the most harmful species and species-transformers. Thirty-one species belong to the class of moderate influence, 19 species - slight effect. For the analysis, such research results were considered: the number of known localities of invasive plants, assessments of their phytocoenotic role in natural plant groups and its dynamics. According to these criteria, four species currently under expansion were identified: Reynoutria japonica Houtt., Impatiens parviflora DC., Echinocystis lobata (Michx.) Torr. et Gray, Bidens frondosa. Also, in the last 5-7 years, the rate of distribution and naturalisation of species such as Quercus rubra L., Asclepias syriaca, Parthenocissus quinquefolia (L.) Planch., Prunus cerasifera Ehrh., Elaeagnus rhamnoides (L.) A. Nelson, Oenothera biennis L., which are intensively naturalised as part of native plant communities, Brassica napus L., Lepidium densiflorum Schrad., Galeopsis ladanum L., Ambrosia artemisiifolia L., Lactuca serriola L., Setaria italica subsp. pycnocoma, occupy new anthropogenic habitats. Quercus rubra, native to North American, supersede other tree species' forest communities, especially Quercus robur L., a dominant or subdominant species of some types of forests in

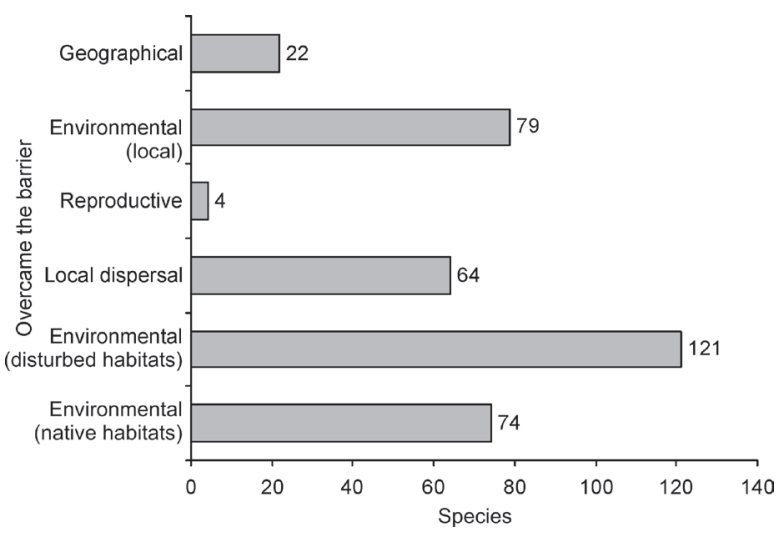

Fig. 2. Quantity of species of alien plants of the flora of Volyn' Polissya of Ukraine according to the degree of naturalisation (based on barriers that are overcome) 
the region (Shelyag-Sosonko, 1985). Parthenocissus quinquefolia, being liana, grows very rapidly between tree stems, shades plants of the lower layer. In this way, it significantly changes the species composition of herbaceous plants and low shrubs in forest communities. Asclepias syriaca forms dense thickets with a projection cover of up to $40-30 \%$ in the ecotone between forest and grassland or rarefied forest communities with projection covering of trees to $40-60 \%$. Prunus cerasifera is increasingly found in natural shrub communities on the outskirts of the forest and the meadows. Hippophae rhamnoides actively migrate into seminatural and natural habitats from their artificially created plantations. It forms very dense, almost mono-species groups on the poor sandy soils of Polissya. As part of the psammophytic communities that have been formed in open, well-illuminated areas, the dominant or subdominant is often Oenothera biennis. In such conditions, this species is a strong competitor for most native species of the Polissya flora. The examples of naturalisation of alien plants presented now have a local character and limited distribution, but they increasingly acquire the properties of invasions and the tendency of further spread (OyTsyus', 2011).

Analysis of the main factors of introduction and distribution of alien plants in the territory of Volyn' Polissya of Ukraine gives grounds to claim that agricultural production, cultivation of introduced plants, urbanisation, and transport infrastructure development contribute to biological pollution. The action of these factors takes place against the background of anthropogenic transformation of native habitats, which primarily causes a violation of the structure of the soil properties (Volodymyrets' \& SHKLYARUK, 2006; HUTSMAN et al., 2009; OYTSYUS', 2011; VOLODYMYRETS' et al., 2013).

An essential source of increasing the number of alien flora is artificial plantations of cultivated plant species. More and more species are gaining the ability to reproduce them and are naturalised primarily because of global climate change to increase the average winter temperature. The flora of Volyn' Polissya includes more than 145 species that have been cultivated and then become wild (OYTSYUs', 2011). The cultivation of new species requires strict control to prevent plant invasions (IvAshCHENKo \& BURDA, 2014).
Many alien species in Volyn' Polissya have become invasive plants due to biological pollution. New taxa replenish region's flora, and for some species, their ecological role increases significantly. Some species can dramatically change the structure of plant groups in the future and reduce by $10-15 \%$ the share of indigenous plant communities.

\section{REFERENCES}

Blackburn T., Essl F., Evans T., Hulme P., Jeschke J., Pergl J., Kühn I., Kumschick S., Marková Z., Mrugala A., Nentwig W., Pyšek P., Rabitsch W., Ricciardi A., Richardson D.M., Sendek A., Vilà M., Wilson J., Winter M., GenOVESI P., BACHER S., 2014: A unified classification of alien species based on the magnitude of their environmental impacts. - PLoS Biology, 12(5): e1001850.

Branquart E., Brundu G., Buholzer S., Chapman D., Ehret P., Fried G., Starfinger U., VAlkenburg J. Van, TANner R., 2016: A prioritization process for invasive alien plant species incorporating the requirements of EU Regulation no. 1143/2014. - EPPO Bulletin, 46: 603-617. https://doi.org/10.1111/epp.12336.

BURDA R., 2006: Fytoynvazyy v agroekosystemax. Synantropyzacyja roslynnoho pokryvu Ukrayny (m. Pereiaslav-Khmel'nyts'kyi, 27-28 kvytnyja 2006): tezy naukovyx dopovydej: 22-24. - Kyiv, Pereiaslav-Khmel'nyts'kyi.

BuRDA R., 2017: Pryxovany ryzyky rozpovsyudzennyja vselentsyv-efemerofytyv u agrarnyx byotopax Ukrayny. - Faktory eksperymental'noj evoljucyy orhanyzmyv, 21: 23-27.

Burda R., Pashkevych N., Boyko H., Fitsaylo T., 2015: Čuzorydny vydy oxoronnyx flor Lysostepu Ukrayny. - Naukova dumka: 118. - Kyiv.

Carboneras C., Genovesi P., Vilà M., Blackburn T., Carrete M., Clavero M., D'hondt B., Orueta J., Gallardo B., Geraldes P., GonzálezMoreno P., Gregory R., Nentwig W., Paquet J., Pyšek P., Rabitsch W., Ramírez I., Scalera R., Tella J., Walton P., Wynde R., 2017: Data from: A prioritised list of invasive alien species to assist the effective implementation of EU legislation. - Dryad Digital Repository. http://doi.org/10.5061/dryad.5fm00. 
European Commission, 2017: Commission Implementing Regulation (EU) 2017/1263 of 12 July 2017 updating the list of invasive alien species of Union concern established by Commission Implementing Regulation (EU) No 2016/1141 pursuant to Regulation (EU) No 1143/2014 of the European Parliament and of the Council. OJ L 182 (13.07.2017), 37.

Hutsman S., Shklyaruk L., Volodymyrets' V., 2009: Adventyvnyj komponent spontannoj flory myst Volyns'koho Polyssyja. - Naukovyj vysnyk Volyns'koho nacyonal'noho unyversytetu ymeny Lesy Ukraynky, 9: 117-123.

IvANYUTA S. ta in., 2020: Zmyna klymatu: naslydky ta zaxody adaptacyy: analyt. dopovyd'. - NISD: 110. - Kyiv. https://niss.gov.ua/sites/default/ files/2020-10/dop-climate-final-5_sait.pdf.

IvASHCHENKO O., BURDA R., 2014: Yevropejs'ka polytyka ščodo ynvazyjnyx čuzorydnyx vydyv roslyn ta perspektyvy yii zaprovadzennyja v Ukrayny. Naukovy pracy Ynstytutu Byoenergetyčnyx kul'tur y cukrovyx buryakyv, 20: 46-54.

KornÁs J., 1968: A geographical-historical classification of synanthropic plants. -Mater. Depart. Phytosoc. Appl. U.W., 25: 33-41.

LuKAsh O., 2009: Adventization of the flora of vascular plants of East Polissya. - Ukrainian Botanical Journal., 66(4): 507-517.

McNeely J., Mooney H., Neville L., Schei P., WAage J., 2001: Global Strategy on Invasive Alien Species. - IUCN: 50. - Switzerland \& UK.

Mosyakin S., 2009: An overview of main hypotheses of plant invasiveness. - Ukrainian Botanical Journal, 66(4): 466-476.

Natsional'nyy Atlas Ukrayny, 2008. - DNVP "Kartohrafyja: 222-225. - Kyiv.

OYtsyus' L., 2011: Adventyvna frakcyja flory Volyns'koho Polyssyja: Avtoreferat dysertacyy kandydata byolohyčnyx nauk: 18. - Kyiv.

Protopopova V., 1991: Synantropnaja flora Ukrayny y puty ee razvytyja. - Naukova dumka: 204. Kyiv.

Protopopova V.V., Shevera M.V., 2014: Ergasiophytes of the Ukrainian flora. - Biodiversity: Research and Conservation, 35: 31-46.

Protopopova V., Mosyakin S., Shevera M., 2002: Fytoynvazyy v Ukrayny iak zahroza byoryznom- anyttyju: sučasnyy stan y zavdannyja na maybutnye. - Ynstytut Botanyky ym. M.H. Xolodnoho NAN Ukrayny: 32. - Kyiv.

Protopopova V., Mosyakin S., Shevera M., 2003: Vplyv adventyvnyx vydyv roslyn na fytobyotu Ukrayny. - Otsynka y napryamky zmenšennyja zahroz byoryznomanyttyju Ukrayny: 129-155. Kyiv.

RAunkiaer C., 1934: The life forms of plants and statistical plant geography. -632 . - London.

Richardson D., Pyšek P., Rejmanek M., Barbour M., Panetta F., West C., 2000: Naturalization and invasion of alien plants: concepts and definitions. Diversity and Distributions, 6: 93-107.

Roy H., Adriaens T., Aldridge D., Bacher S., Bishop J., Blackburn T., Branquart E., Brodie J., Carboneras C., Cook E., Copp G., Dean H., Eilenberg J., Essl F., Gallardo B., Garcia M., García-Berthou E., Genovesi P., Hulme P., Kenis M., Kerckhof F., Kettunen M., Minchin D., Nentwig W., Nieto A., Pergl J., Pescott O., Peyton J., Preda C., Rabitsch W., Roques A., Rorke S., Scalera R., Schindler S., Schönrogge K., Sewell J., Solarz W., Stewart A., Tricarico E., Vanderhoeven S., Van Der Velde G., Vilà M., Wood C., Zenetos A., 2015: Invasive alien species - prioritising prevention efforts through horizon scanning. - European Commission (ENV.B.2/ETU/2014/0016). - Brussels.

Shelyag-Sosonko Yu.R. (ed.), 1985: Pryroda Ukraynskoj SSR. Rastytel'nyj myr: 208. - Kyiv.

TAKHTAJAN A., 1986: Floristic regions of the world: 522. - Berkeley \& Los Angeles.

The information resource for Euro-Mediterranean plant diversity. 2011. http://www.emplantbase. org/home.html. [Accessed 12 April 2021]

Volodymyrets' V., Shklyaruk L., 2006: Ahrovyrobnyctvo jak faktor rozpovsyudzennyja adventyvnyx vydyv roslyn na terytoryy Volyns'koho Polyssyja. - Vysnyk NUVHP: Zbyrnyk naukovyx prats', 4(36), 1: 52-58.

Volodymyrets' V., Oytsyus' L., Solodka T., 2013: Adventyzacyja spontannoj flory Volyns'koho Polyssyja. - Vysnyk NUVHP: Zb. nauk. pr. Syl's'kohospodars'ky nauky, 1(61): 153-165.

Whittaker R., 1975: Communities and Ecosystems. - Macmillan: 385. - New York. 
BIOLOGINĖ FLOROS TARŠA SVETIMŽEMIAIS AUGALAIS UKRAINOS VOLYNĖS POLESIEJE

\section{Vitaliy VOLODYMYRETS, Larisa OYTSIUS, Serhiy HUTSMAN, Lyubov SAVCHUK}

\section{Santrauka}

Darbo tikslas buvo išanalizuoti vietinès Volynès Polesieje floros biologinès taršos svetimžemiais augalais procesus. Vietineje Volynès Polesieje floroje buvo nustatyti 364 svetimžemiai augalai, priklausantys 228 gentims ir 68 šeimoms. Skaitlingiausios svetimžemių augalų šeimos regiono floroje buvo: Asteraceae, Brassicaceae, Poaceae, Rosaceae, Chenopodiaceae, Fabaceae, Lamiaceae, Solanaceae ir Caryophyllaceae. Keturios svetimžemès rūšys: Reynoutria japonica, Impatiens parviflora, Echinocystis lobata ir Bidens frondosa šiuo metu yra agresyvaus plitimo stadijoje. Pagal kilmę regiono svetimžemių rūšių floroje vyrauja ateiviai iš Viduržemio jūros, Irano-Turano ir Atlanto-Šiaurès Amerikos floris- tinių regionų. Pagal natūralizacijos laipsnį vyrauja svetimžemès rūšys, kurios įveikè žmogaus paveiktos aplinkos barjerą. Per pastaruosius 30-50 metų i Volynès Polesieje buvo įvežta mažiausiai 80 naujų svetimžemių augalų rūšių. Per pastaruosius 5-7 metus paspartėjo tokių rūšių, kaip Quercus rubra, Asclepias syriaca, Parthenocissus quinquefolia, Prunus cerasifera, Hippophae rhamnoides ir Oenothera biennis paplitimo ir natūralizacijos greitis. Šios rūšys intensyviai skverbiasi ị vietines augalų bendrijas. Volynès Polesieje floros taršą sąlygoja svetimžemių rūšių migracija iš žemès ūkio paskirties žemių, introdukuotų augalų invazija, urbanizacija ir transporto infrastruktūros plètra. 